\title{
Selective Chromogenic Recognition of Copper(II) Ion by Thiacalix[4]arene Tetrasulfonate and Mechanism
}

\author{
Shufang Zhu ${ }^{1,2}$ and Lilin Lu ${ }^{1,3, * \mathbb{C}}$ \\ 1 College of Resource and Environmental Engineering, Wuhan University of Science and Technology, \\ Wuhan 430081, China; zhushufang@wust.edu.cn \\ 2 State Key Laboratory of Refractories and Metallurgy, Wuhan University of Science and Technology, \\ Wuhan 430081, China \\ 3 Hubei Province Key Laboratory of Coal Conversion and New Carbon Materials, \\ School of Chemistry and Chemical Engineering, Wuhan University of Science and Technology, \\ Wuhan 430081, China \\ * Correspondence: lulilin@wust.edu.cn
}

Received: 13 January 2020; Accepted: 28 January 2020; Published: 30 January 2020

\begin{abstract}
Detection of biologically important transition metal ions such as copper by using a simple method is desirable and of great importance. In this work, we firstly reported that water-soluble thiacalix[4]arene tetrasulfonate (TCAS) exhibited selective chromogenic recognition towards copper(II) ion over other transition metal ions. Color change from colorless to salmon pink was observed in TCAS solution, weak bathochromic shift was induced in UV absorption spectrum of TCAS upon addition of copper(II) ion, and the absorbance of characteristic absorption band at $312 \mathrm{~nm}$ increased linearly with copper(II) ion concentration. The recognition mechanism of TCAS to copper(II) ion was investigated by a comparative study with calix[4]arene tetrasulfonate (CAS) and time-dependent density functional theory(TD-DFT) study, and the absorption bands were assigned based on transition orbital analysis.
\end{abstract}

Keywords: thiacalix[4]arene tetrasulfonate; copper (II); chromogenic recognition; mechanism

\section{Introduction}

Over the past decades, considerable efforts have been devoted to the development of molecular receptors for the recognition of biologically important transition metal ions. Copper, whose abundance ranks third in the human body, plays an important role in diverse fundamental physiological processes, i.e., the biosynthesis of hemoglobin, bone development, and the regulation of nerve functions [1,2]. Excessive or inadequate uptake of copper will cause several health hazards [3,4]; therefore, it is very important and meaningful to develop simple techniques such as chromogenic recognition, to detect copper in the environment and biological systems.

Calixarenes are one of the most extensive molecular scaffolds for the development of chromogenic reagents for selective recognition towards metal ions, such as alkali/alkaline earth ions [5-8], transition metal ions [9-12], lanthanide and actinide ions [13-15], and heavy metal ions [16-18]. Much attention has been paid in recent years to the detection of $\mathrm{Cu}^{2+}$ ion due to its considerable health and environmental demands. Qazi et al. synthesized a calix[4]arene derivative that has a highly selective chromogenic response to copper ion [19], and thiacalix[4]arene-based imino receptors carrying azophenol appendage were found to show highly selective chromogenic sensing for $\mathrm{Cu}^{2+}$ ions over other metal ions by Kumar et al. [20]. Chawla et al. have synthesized calix[4]arene bearing Schiff base loop at the lower rim, which showed chromogenic responses to $\mathrm{Cu}^{2+}$ [21]; furthermore, a novel calix[4]dicyano-diimidazole thin film has been developed by Rouis et al. for optical sensing $\mathrm{Cu} 2+$, whose the limit of detection is about 
$7.0 \times 10^{-9} \mathrm{~mol} \cdot \mathrm{L}^{-1}[22]$. The inherent defects of calixarene derivatives such as poor water-solubility and complicated synthesis process, however, prevent them from wide usage in biological and environmental fields. Synthesis-facile and water-soluble chromogenic sensors based on calixarene and its derivatives, which can realize the favorable recognition of copper ion, are desirable.

Thiacalix[4]arene tetrasulfonate (TCAS, Figure 1), a water-soluble derivative of calix[4]arene with a heteratom bridge atom between its phenol units, has been studied in some previous works [23,24]. The crystal structures of a few copper complexes of TCAS have been investigated to clarify the coordination site between TCAS and copper [25,26]. In this work, we firstly reported the highly selective chromogenic recognition behavior of TCAS towards copper(II) ion over other first row transition metal ions. More promisingly, the topic compound TCAS possesses simple preparation procedure and excellent water-solubility. The chromogenic recognition mechanism of TCAS towards copper(II) ion was explored by comparative study with calix[4]arene tetrasulfonate (CAS, Figure 1) and quantum chemical calculations based on time-dependent density functional theory.

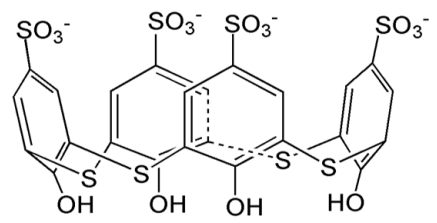

Thiacalix[4] arene tetrasulfonate (TCAS)

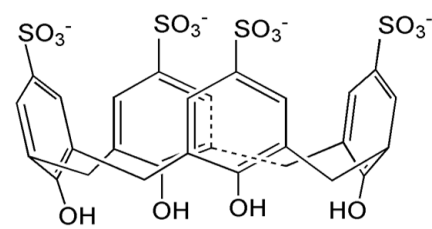

Calix[4]arene tetrasulfonate (CAS)

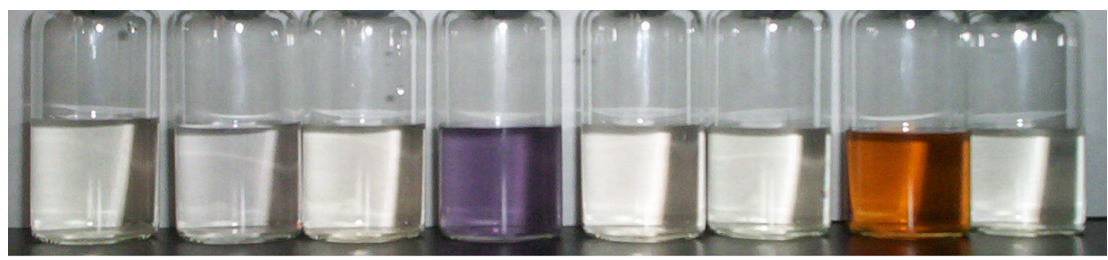

TCAS TCAS/Cr TCAS/Mn TCAS/Fe TCAS/Co TCAS/Ni TCAS/Cu TCAS/Zn

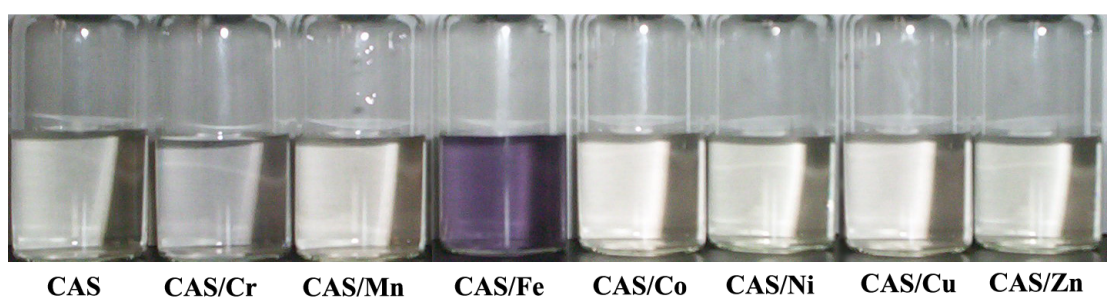

Figure 1. The molecular structures of thiacalix[4]arene tetrasulfonate (TCAS) and calix[4]arene tetrasulfonate (CAS), and color change in aqueous solution of TCAS and CAS upon addition of transition metal ions. The concentrations of TCAS and CAS are both $4.3 \times 10^{-3} \mathrm{~mol} \mathrm{~L}^{-1}$, and the concentrations of all transition metal ions are $9.5 \times 10^{-5} \mathrm{~mol} \cdot \mathrm{L}^{-1}$.

\section{Results and Discussion}

\subsection{Chromogenic Response of TCAS to Transition Metal Ions in Aqueous Solution}

The chromogenic response of TCAS to the investigated first-row transition metal ions is displayed in Figure 1. As shown, remarkable color changes were induced by iron(III) and copper(II) ions, TCAS aqueous solution changed from colorless to purple when iron(III) ion was added, and orange appeared after addition of copper(II) ion. However, TCAS showed no distinct chromogenic response towards other transition metal ions, such as $\mathrm{Cr}(\mathrm{III}), \mathrm{Mn}(\mathrm{II}), \mathrm{Co}(\mathrm{II}), \mathrm{Ni}(\mathrm{II})$, and $\mathrm{Zn}(\mathrm{II})$ ions, demonstrating the selective chromogenic recognition of TCAS towards iron(III) and copper(II) ions.

It is well known that purple complex can be generally formed between phenol and iron(III) ion; the purple chromogenic response of TCAS was suspected to be the similar response of phenolic compounds to iron(III) ion. To verify this point, control experiments were performed by the addition of iron(III) ion to the aqueous solution of phenol and CAS (Figure 1). As expected, purple presented in 
both phenol aqueous solution and CAS solution, indicating that the purple chromogenic response is not a distinctive response of TCAS to iron(III) ion. Additionally, copper(II) ion was, respectively, added to phenol and CAS aqueous solutions, but no obvious chromogenic response was observed in them, which indicates that the orange chromogenic response is the distinctive and selective recognition of copper(II) ion by TCAS, which can be easily detected with the naked eye.

\subsection{Absorption Spectra of TCAS-Cu Solution and the Effect of Copper Ion Concentration}

UV/Visible absorption spectra of TCAS and TCAS-copper(II) aqueous solution were recorded to investigate the influence of copper(II) ion on the absorption property of TCAS. As shown in Figure 2a, two main absorption bands at 205 and $307 \mathrm{~nm}$ appeared in the absorption spectrum of TCAS $\left(4.5 \times 10^{-5} \mathrm{~mol} \cdot \mathrm{L}^{-1}\right)$. In the absorption spectrum of TCAS-copper(II) aqueous solution, the absorption bands shifted to 210 and $312 \mathrm{~nm}$, respectively, meaning approximately $5 \mathrm{~nm}$ bathochromic shift of main absorption bands. In addition, distinct enhancement was induced in absorption intensity of the main absorption bands by copper(II) ion.
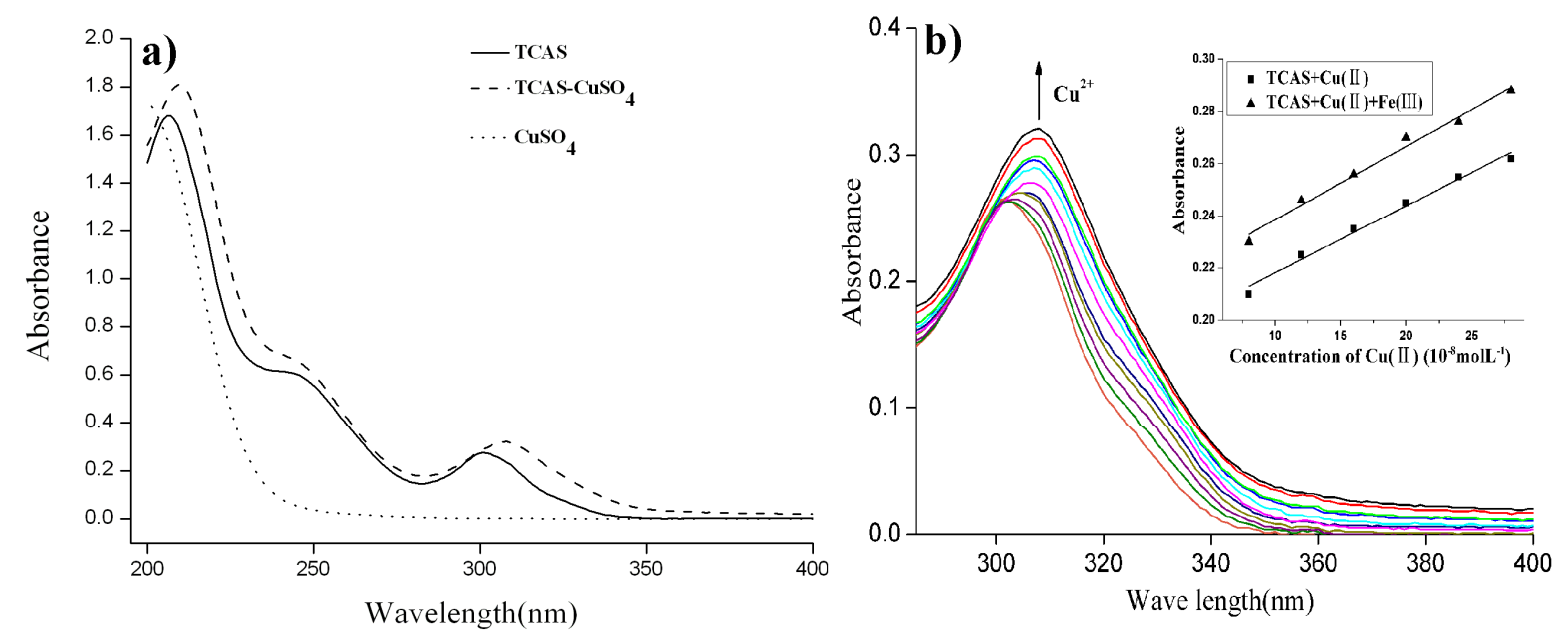

Figure 2. (a) Absorption spectra of TCAS $\left(4.5 \times 10^{-5} \mathrm{~mol} \cdot \mathrm{L}^{-1}\right), \mathrm{CuSO}_{4}$, and TCAS-CuSO 4 aqueous solution; (b) effect of $\mathrm{Cu}$ (II) concentration on absorbance at $312 \mathrm{~nm}$ and linear relation in $\mathrm{Cu}$ (II) concentration range of $0.8-2.8 \times 10^{-7} \mathrm{~mol} \cdot \mathrm{L}^{-1}$ with and without $\mathrm{Fe}(\mathrm{III})$ ion (shown in the inserts).

To explore the origin of the remarkable change in absorption spectra, the UV-vis spectrum of $\mathrm{CuSO}_{4}$ aqueous solution was also recorded for comparison. As can be seen from Figure 2a, no detectable absorption feature presented in $250 \sim 400 \mathrm{~nm}$ in $\mathrm{CuSO}_{4}$ absorption spectrum, and the absorption bands were only located in the range of less than $250 \mathrm{~nm}$, which revealed that coordination reaction between TCAS and copper(II) ion, rather than the superimposition effect of the absorption band of TCAS and copper(II) ion, resulted in distinct enhancement of absorption intensity.

The effects of copper(II) ion concentration on absorbance at 210 and $312 \mathrm{~nm}$ of $\mathrm{Cu}$ (II)-TCAS solution were investigated. Continuous increase in absorbance at 312nm along with the augment of copper(II) ion concentration was observed (Figure $2 \mathrm{~b}$ ), and a linear relations between absorbance and copper(II) ion concentration in the range of $0.8 \times 10^{-7}$ to $2.8 \times 10^{-7} \mathrm{~mol} \cdot \mathrm{L}^{-1}$ was presented. The linear regression equation was determined to be absorbance $(\mathrm{A})=0.002571 \times \mathrm{C}\left(10^{-8} \mathrm{~mol} \cdot \mathrm{L}^{-1} \mathrm{Cu}(\mathrm{II})\right)+0.1924$, $\mathrm{r}=0.994, \mathrm{n}=6$. However, there was no continuous increase in absorbance at $210 \mathrm{~nm}$ and no linear relationship between the absorbance at $210 \mathrm{~nm}$ and copper(II) ion concentration. To investigate the influence of iron(III) ion, the absorbance of aqueous solution containing $4.5 \times 10^{-5} \mathrm{~mol} \cdot \mathrm{L}^{-1} \mathrm{TCAS}$, $8.0 \times 10^{-5} \mathrm{~mol} \cdot \mathrm{L}^{-1} \mathrm{Fe}(\mathrm{III})$ ion, and $(0.8 \sim 2.8) \times 10^{-7} \mathrm{~mol} \cdot \mathrm{L}^{-1} \mathrm{Cu}(\mathrm{II})$ ion, at $312 \mathrm{~nm}$, were measured and shown in the insert in Figure 2b; the result indicates that the presence of Fe(III) ion does not show distinct effect on the linear relations between absorbance and copper(II) ion concentration, despite a slight increase in the absorbance. These results indicated TCAS displayed a highly selective and 
distinctive chromogenic recognition to copper(II) ion over other transition metal ions, and quantitative detection of copper(II) ion can be implemented in the range of $0.8 \times 10^{-7}$ to $2.8 \times 10^{-7} \mathrm{~mol} \cdot \mathrm{L}^{-1}$ by TCAS.

\subsection{The Mechanism of Selective Chromogenic Response of TCAS to Copper Ions}

By comparison of the molecular structure of TCAS and CAS, possible mechanism of distinctive chromogenic recoginition of TCAS towards copper(II) ion can be inferred as the complexation between TCAS and copper(II) ion via the bridge sulfur atom site. This complexation structure between TCAS and copper(II) ion had been reported in previous experimental work $[25,26]$.

To verify this point, Time-Dependent Density Functional Theory (TDDFT) [27] calculations were performed to investigate the effect of coordination between TCAS and copper(II) ion on the UV/Visible absorption properties. To circulate the vast calculation cost caused by the considerable size of calixarene molecule, a representative computation model of TCAS-Cu complex was selected to perform quantum chemical calculation. The experimental and theoretical absorption spectrum in aqueous solution were displayed in Figure 3, and theoretical absorbance was scaled so as to compare with experimental spectrum.
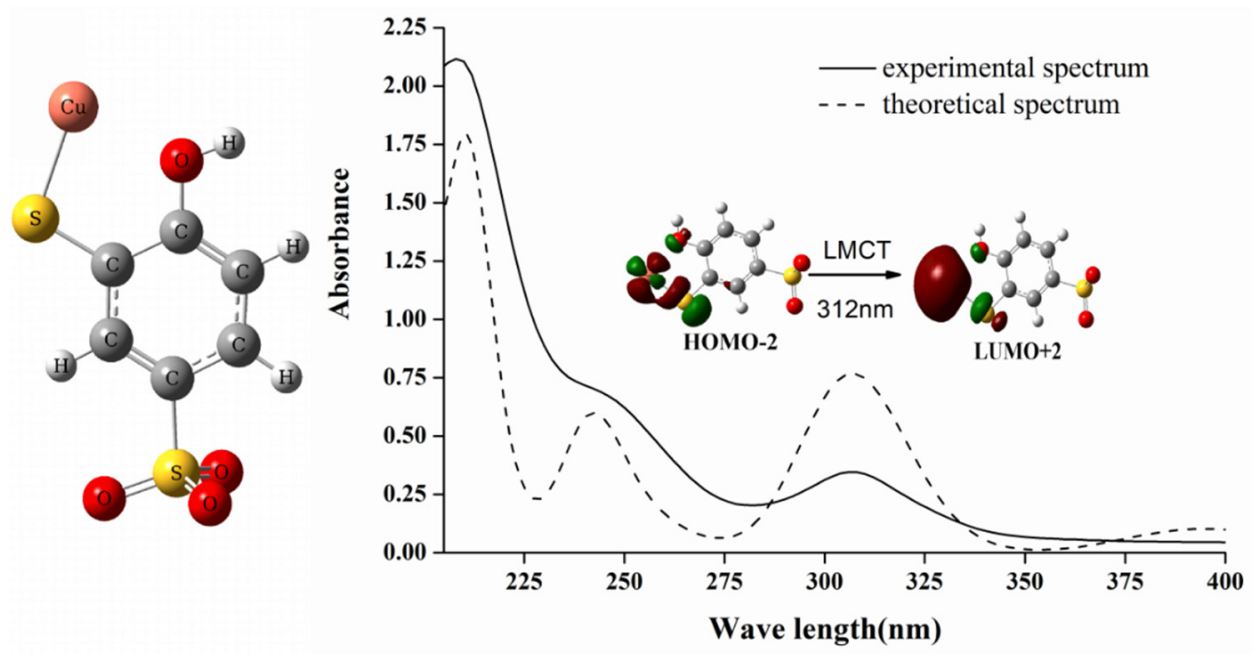

Figure 3. Theoretical model of TCAS-Cu complex (left), and experimental and theoretical UV absorption spectrum of TCAS-Cu complex (right).

As can be seen from Figure 3, the theoretical spectrum was in excellent agreement with experimental spectrum, and the main absorption bands at 210, 242, and $312 \mathrm{~nm}$ in experimental spectrum were all accurately reproduced by theoretical calculation. Table 1 lists the three main absorption bands and orbital contributions, and the topologies of selected molecular orbital involved in electronic transitions are shown in Figure 4 to provide deep insight into the nature of UV/Vis absorption bands. The main contributions to $210 \mathrm{~nm}$ absorption band were $\mathrm{HOMO}-1$ to $\mathrm{LUMO}+3, \mathrm{HOMO}-3$ to $\mathrm{LUMO}+1$, $\mathrm{HOMO}-9$ to $\mathrm{LUMO}+3$, and HOMO -5 to LUMO + 1 electron transitions; their topological analysis indicated that these orbitals were of $\pi$-nature, and that this absorption band can be assigned as $\pi \rightarrow \pi^{*}$ transition of benzene ring. Additionally, metal-ligand charge transfer (MLCT) transition from copper to benzene ring also contributed to this absorption band. The contributions to $242 \mathrm{~nm}$ band were $\mathrm{HOMO}-1$ to LUMO +1 and HOMO -3 to LUMO +3 transitions, and the transition character was similar to the absorption band at $210 \mathrm{~nm}$. The maximum contribution to $312 \mathrm{~nm}$ band was HOMO - 2 to LUMO + 2 transition, mainly spread over copper(II) and sulfur. From the orbital topology, HOMO-2 can be described as Cu-S coordination bond orbital; LUMO + 2 was the orbital with copper(II) ion 4s orbital character, and the transition between them can be assigned as ligand to metal charge transfer (LMCT) transition corresponding to $312 \mathrm{~nm}$ absorption band. 
Table 1. Experimental and theoretical absorption bands, oscillator strengths, and orbital transition contributions.

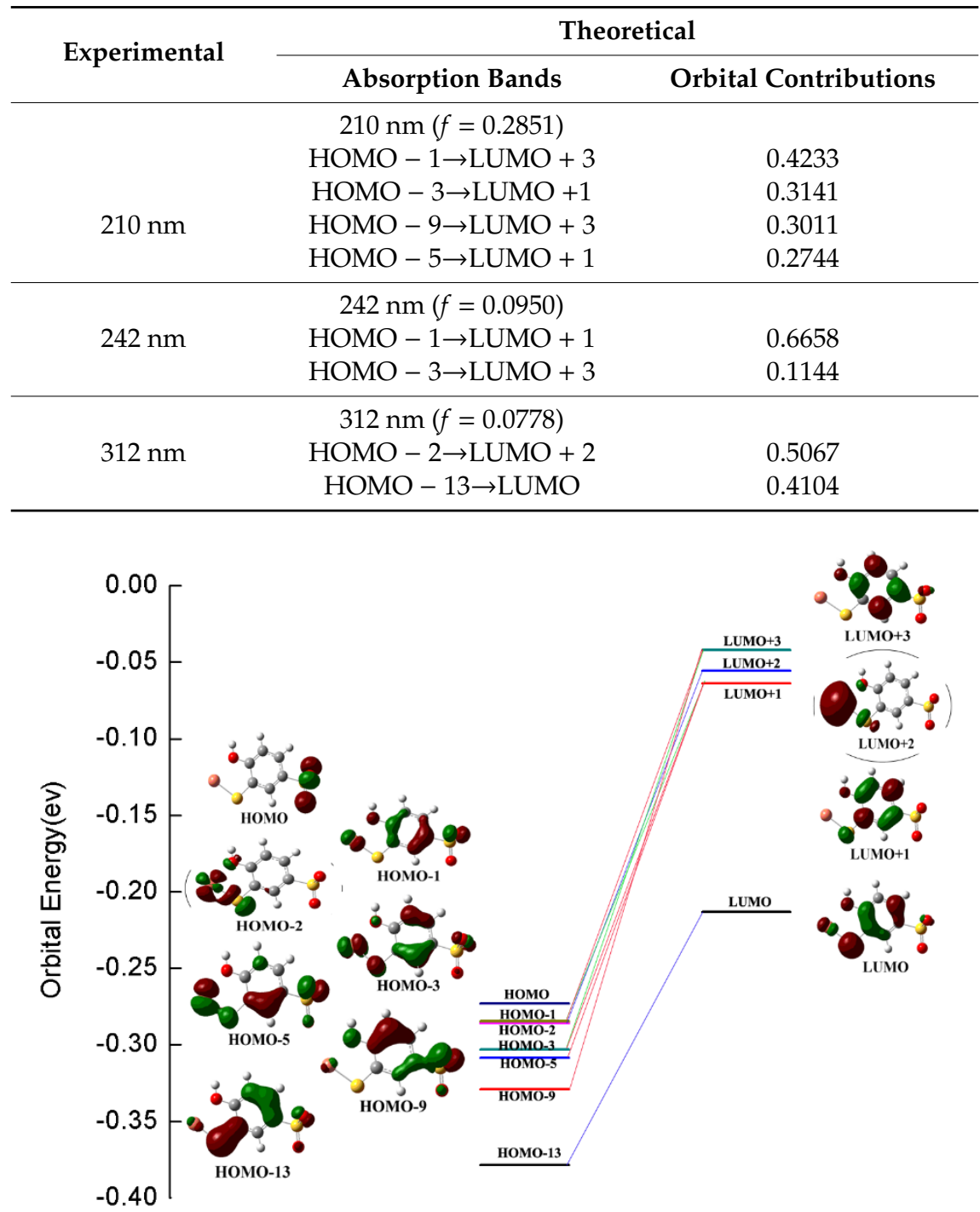

Figure 4. Topologies of molecular orbital involved in electronic transitions of main absorption bands.

\section{Materials and Methods}

Thiacalix[4]arene tetrasulfonate(TCAS) was synthesized according to the methods reported in literature [23,24]. Transitional metal ions $\mathrm{Cr}(\mathrm{III}), \mathrm{Mn}(\mathrm{II}), \mathrm{Fe}(\mathrm{III}), \mathrm{Co}(\mathrm{II}), \mathrm{Ni}(\mathrm{II}), \mathrm{Cu}(\mathrm{II})$, and $\mathrm{Zn}$ (II) were offered in commercial inorganic salt $\left(\mathrm{CrCl}_{3}, \mathrm{MnSO}_{4}, \mathrm{FeCl}_{3}, \mathrm{Co}\left(\mathrm{NO}_{3}\right)_{2}, \mathrm{NiSO}_{4}, \mathrm{CuSO}_{4}\right.$, and $\left.\mathrm{ZnSO}_{4}\right)$ of analytical grade and used without further purification, and the stock aqueous solutions were prepared by using double distilled water. Five hundred microlitres of stock solution $\left(2.0 \times 10^{-3} \mathrm{~mol} \cdot \mathrm{L}^{-1}\right)$ of transitional metal ions was added to $10 \mathrm{~mL}$ TCAS solution $\left(4.5 \times 10^{-3} \mathrm{~mol} \cdot \mathrm{L}^{-1}\right)$ and $10 \mathrm{~mL}$ CAS solution $\left(4.5 \times 10^{-3} \mathrm{~mol} \cdot \mathrm{L}^{-1}\right)$, respectively, while constantly stirring at room temperature, and the color changes were recorded immediately. UV/Visible absorption spectra were recorded on a UV-2550 spectrophotometer (Shimadzu, Tokyo, Japan). A certain amount of $\mathrm{Cu}$ (II) ion stock solution $\left(2.0 \times 10^{-3} \mathrm{~mol} \cdot \mathrm{L}^{-1}\right)$ was added to $1 \mathrm{~mL}$ TCAS solution $\left(4.5 \times 10^{-3} \mathrm{~mol} \cdot \mathrm{L}^{-1}\right)$, and the final volume of the solution was adjusted to $100 \mathrm{~mL}$ with double distilled water. Two minutes later, the absorbance was measured at $312 \mathrm{~nm}$ in $1 \mathrm{~cm}$ quartz cell against water blank at room temperature.

GAUSSIAN03 program package [28] was chosen to perform geometries optimizations, vibrational analysis, and excitation energy investigation. The stable stationary points of structures were obtained by geometry optimization at B3LYP/6-311+G(d,p) level with the default convergence criteria, 
and vibrational frequency calculations were performed to confirm all frequency were real at the same computation level. Time-dependent parameter-free PBE0 hybrid functional and 6-311++G(2d,2p) basis sets were chosen to calculate vertical electronic excitation energies without zero-point energy correction, and bulk solvent effect was evaluated by the SCRF method via polarized continuum model (PCM). All solvent parameters are default-implemented in Gaussian program.

\section{Conclusions}

The addition of copper(II) ions to thiacalix[4]arene tetrasulfonate(TCAS) induced a distinct chromogenic response, in which colorless TCAS aqueous solution changed to salmon pink when copper(II) ion solution was added. The main bands in the absorption spectrum exhibited weak bathochromic shift; there was a linear relationship between the absorption band intensity at $312 \mathrm{~nm}$, and copper(II) ion concentration was determined to be absorbance $(\mathrm{A})=0.002571 \times \mathrm{C}\left(10^{-8} \mathrm{~mol} \cdot \mathrm{L}^{-1}\right.$ $\mathrm{Cu}(\mathrm{II}))+0.1924$ in the concentration range of $0.8 \times 10^{-7}$ to $2.8 \times 10^{-7} \mathrm{~mol} \cdot \mathrm{L}^{-1}$. Time-dependent density functional theory studies revealed that the coordination between bridge sulfur atom of TCAS and copper(II) ion is the origin of the chromogenic response of TCAS to copper(II) ion, and the characteristic absorption band at $312 \mathrm{~nm}$ was assigned as ligand to metal charge transfer (LMCT) transition based on transition orbital analysis.

Author Contributions: Conceptualization, L.L.; Data curation, S.Z.; Formal analysis, S.Z. and L.L.; Funding acquisition, S.Z. and L.L.; Investigation, S.Z. and L.L.; Methodology, S.Z. and L.L.; Project administration, L.L.; Supervision, L.L.; Validation, S.Z. and L.L.; Writing-original draft, S.Z. and L.L.; Writing-review \& editing, L.L. All authors have read and agreed to the published version of the manuscript.

Funding: This work was financially supported by the National Natural Science Foundation of China (U1732147, 21671154) and Foundation of Hubei Educational Committee (B2015354).

Conflicts of Interest: The authors declare no conflict of interest. The funders had no role in the design of the study; in the collection, analyses, or interpretation of data; in the writing of the manuscript and in the decision to publish the results.

\section{References}

1. Andreini, C.; Banci, L.; Bertini, I.; Rosato, A. Occurrence of Copper Proteins through the Three Domains of Life: A Bioinformatic Approach. J. Proteome Res. 2008, 7, 209-216. [CrossRef] [PubMed]

2. Harris, E.D. Copper and iron: A Landmark Connection of Two Essential Metals. J. Trace Elem. Exp. Med. 2001, 14, 207-210. [CrossRef]

3. Waggoner, D.J.; Bartnikas, T.B.; Gitlin, J.D. The Role of Copper in Neurodegenerative Disease. Neurobiol. Dis. 1999, 6, 221-230. [CrossRef] [PubMed]

4. Vulpe, C.; Evinson, B.; Whitney, S.; Packman, S.; Gitschier, J. Isolation of a candidate gene for Menkes disease and evidence that it encodes a copper-transporting ATPase. Nat. Genet. 1993, 3, 7-13. [CrossRef] [PubMed]

5. Lee, S.H.; Kim, J.Y.; Ko, J.; Lee, J.Y.; Kim, J.S. Regioselective Complexation of Metal Ion in Chromogenic Calix[4]biscrowns. J. Org. Chem. 2004, 69, 2902-2905. [CrossRef]

6. Tsuda, D.; Nakdhara, Y.; Machitani, K.; Kannaka, M.; Takahashi, E.; Kimura, K. Ultra-High-Sensitive Extraction-Photometric Determination of Sodium Ion Using Flow Injection Analysis with a Chromogenic Calix[4]arene Derivative and a Laser Interferometric Photothermal Detector. Anal. Chem. 2012, 84, 3710-3715. [CrossRef]

7. Nabeshima, T.; Saiki, T.; Iwabuchi, J.; Akine, S. Stepwise and Dramatic Enhancement of Anion Recognition with a Triple-Site Receptor Based on the Calix[4]arene Framework Using Two Different Cationic Effectors. J. Am. Chem. Soc. 2005, 127, 5507-5511. [CrossRef]

8. Kim, S.K.; Lee, S.H.; Lee, J.Y.; Lee, J.Y.; Bartsch, R.A.; Kim, J.S. An Excimer-Based, Binuclear, On-Off Switchable Calix[4]crown Chemosensor. J. Am. Chem. Soc. 2004, 126, 16499-16506. [CrossRef]

9. Halouani, H.; Bonnamour, I.D.; Perrin, M.; Lamartine, R. First Synthesis and Structure of $\beta$-Ketoimine Calix[4]arenes: Complexation and Extraction Studies. J. Org. Chem. 2004, 69, 6521-6527. [CrossRef] 
10. Lu, L.; Zhu, S.; Liu, X.; Xie, Z.; Yan, X. Highly selective chromogenic ionophores for the recognition of chromium(III) based on a water-soluble azocalixarene derivative. Anal. Chim. Acta 2005, 535, 183-187. [CrossRef]

11. Bingol, H.; Kocabas, E.; Zor, E.; Coskun, A. Spectrophotometric and electrochemical behaviour of a novel azocalix[4]arene derivative as a highly selective chromogenic chemosensor for $\mathrm{Cr}^{3+}$. Electrochim. Acta 2011, 56, 2057-2061. [CrossRef]

12. Shaabani, B.; Shaghaghi, Z.; Khandar, A.A. Optical spectroscopy studies of the complexation of bis(azaophenol)calix[4]arene possessing chromogenic donors with $\mathrm{Ni}^{2+}, \mathrm{Co}^{2+}, \mathrm{Cu}^{2+}, \mathrm{Pb}^{2+}$ and $\mathrm{Hg}^{2+}$. Spectrochim. Acta Part A Molecular Biomol. Spectr. 2012, 98, 81-85. [CrossRef] [PubMed]

13. Liu, J.M.; Chen, C.F.; Zheng, Q.Y.; Huang, Z.T. A selective fluorescent probe for $\mathrm{La}^{3+}$ and $\mathrm{Y}^{3+}$ based on calix[6]arene. Tetrahedron Lett. 2004, 45, 6071-6074. [CrossRef]

14. Beer, P.D.; Szemes, F.; Passaniti, P.; Maestri, M. Luminescent Ruthenium(II) Bipyridine-Calix[4]arene Complexes as Receptors for Lanthanide Cations. Inorg. Chem. 2004, 43, 3965-3975. [CrossRef] [PubMed]

15. Ebdelli, R.; Rouis, A.; Mlika, R.; Bonnamour, I.; Ouada, H.B.; Davenas, J. Photo-physical and complexation properties of chromogenic azo-calix[4]arene: Application to the detection of $\mathrm{Eu}^{3+}$. J. Mol. Struct. 2011, 1006, 210-215. [CrossRef]

16. Ho, I.-T.; Lee, G.-H.; Chung, W.-S. Synthesis of upper-rim allyl- and p-methoxyphenylazocalix[4]arenes and their efficiencies in chromogenic sensing of $\mathrm{Hg}^{2+}$ ion. J. Org. Chem. 2007, 72, 2434-2442. [CrossRef] [PubMed]

17. Bingol, H.; Kocabas, E.; Zor, E.; Coskun, A. A novel benzothiazole based azocalix[4]arene as a highly selective chromogenic chemosensor for $\mathrm{Hg}^{2+}$ ion: A rapid test application in aqueous environment. Talanta 2010, 82, 1538-1542. [CrossRef]

18. Chawla, H.M.; Gupta, T. New chromogenic bis(isatin hydrazonyl)calix[4]arenes for dual recognition of fluoride and silver ions. Tetra. Lett. 2013, 54, 1794-1797. [CrossRef]

19. Qazi, M.A.; Qureshi, I.; Memon, S. A highly copper selective chromogenic calix[4]arene dervivative. New J. Chem. 2010, 34, 2579-2586. [CrossRef]

20. Kumar, M.; Babu, J.N.; Bhalla, V.; Dhir, A. Chromogenic sensing of Cu(II) by imino linked thiacalix[4]arene in mixed aqueous environment. Inorg. Chem. Commun. 2009, 12, 332-335. [CrossRef]

21. Chawla, H.M.; Goel, P.; Shukla, R.; Black, D.S.; Kumar, N. New lower rim looped calix[4]arene for ratiometric and chromogenic recognition of $\mathrm{Cu}^{2+}$. J. Incl. Phenom. Macrocycl. Chem. 2014, 80, 201-207. [CrossRef]

22. Rouis, A.; Darbost, U.; Bonnamour, I.; Quada, H.B. Development and characterization of a copper ion-selective optical sensor based on a novel calix[4]dicyano-diimidazole thin film. Mater. Chem. Phys. 2015, 164, 145-149. [CrossRef]

23. Kumagai, H.; Hasegawa, M.; Miyanari, S.; Sugawa, Y.; Sato, Y.; Hori, T.; Ueda, S.; Kamiyama, H.; Miyano, S. Facile synthesis of p-tert-butylthiacalix[4]arene by the reaction of p-tert-butylphenol with elemental sulfur in the presence of a base. Tetra. Lett. 1997, 38, 3971-3972. [CrossRef]

24. Iki, N.; Fujimoto, T.; Miyano, S. A New Water-Soluble Host Molecule Derived from Thiacalixarene. Chem. Lett. 1998, 27, 625-626. [CrossRef]

25. Mislin, G.; Graf, E.; Hosseini, M.W.; Bilyk, A.; Hall, A.K.; Harrowfield, J.M.; Skelton, B.W.; White, A.H. Thiacalixarenes as cluster keepers: Synthesis and structural analysis of a magnetically coupled tetracopper(II) square. Chem. Comm. 1999, 4, 373-374. [CrossRef]

26. Guo, Q.L.; Zhu, W.X.; Gao, S.; Ma, S.L.; Dong, S.J.; Xu, M.Q. A novel 2D coordination polymer based on a copper(II) tetramer with p-sulfonated thiacalix[4]arene. Inorg. Chem. Commun. 2004, 7, 467-470. [CrossRef]

27. Bauernschmitt, R.; Ahlrichs, R. Treatment of electronic excitations within the adiabatic approximation of time dependent density functional theory. Chem. Phys. Lett. 1996, 256, 454-464. [CrossRef]

28. Frisch, M.J.; Trucks, G.W.; Schlegel, H.B.; Scuseria, G.E.; Robb, M.A.; Cheeseman, J.R.; Scalmani, G.; Barone, V.; Mennucci, B.; Petersson, G.A.; et al. Gaussian 03; Revision B.05; Gaussian, Inc.: Pittsburgh, PA, USA, 2003.

Sample Availability: Samples of the compounds are available from the authors. 